\title{
Foreign Policy of the U.S. Towards the Kurds in Turkey and Syria: An Analytical Framework
}

\author{
Oladimeji Talibu (Ph.D) \\ Lecturer, AlHikmah University, Ilorin, Nigeria \\ Mahdi Stoni (M.Sc) \\ Ph.D Candidate, Universiti Utara Malaysia
}

\begin{abstract}
Kurds are one of the ethnic nationalities in the Middle East. Middle East is a principal location of majority of the Kurds' ethnic nationality and they form important minority group in both Syria and Turkey. The region has been their natural abode from the earliest time; and the disintegration of the Ottoman Empire after the First World War had a lasting impact on the political emancipation of the Kurds in the Middle East, notably in Turkey and Syria. With the collateral collapse of the empire under which the Kurds had been ruled for centuries, they were unnaturally conditioned to belong to different national entity in the Middle East. Such unwilling disintegration of Kurds into many states in the Middle East has been a crucial political and social issue in the region. The seemingly unending agitation for political emancipation has been a perennial political issue bothering both regional and global powers who have their interest to protect in the region. One of such major powers is the U.S. who has been making its presence felt in the region since the period of First World War. This article is an extension of boundary of knowledge on how the Kurds political agitation in the region has been inextricably interwoven with the national interest of the U.S. in both Turkey and Syria. In doing this, the researchers rely on the existing government records, online media reports and existing scholarly writings. In making use of these sources, latent content analysis is employed to mine the data.
\end{abstract}

Keywords: Kurds; Foreign Policy; Middle East; National Interest; U.S.

DOI: $10.7176 / \mathrm{IAGS} / 75-03$

Publication date: August $31^{\text {st }} 2019$

\section{Introduction}

The term Middle East today is used to refer to Egypt, the Levant, Arabia, and the Gulf region. The defeat of Ottoman Empire (Turkey) in the First World War and eventual takeover of its former satellites of Arab states led to the general use of the word to all former Turkish possessions (Mansfield, 2013). Therefore, all states encompassing the Middle East region are one of the significant areas in the formulation of the U.S. foreign policy. The U.S. interest in the area is guided by its national security, which is closely tied to economic prosperity and that dictates the direction of its foreign policy towards the region. The expression of Kurdish nationalism started during the 19th century, when the Ottoman Empire was undergoing a process of centralization. Before the centralization process, the Kurdish Emirates had enjoyed some modicum of autonomy. The Kurds had been under the control of Ottoman authority as early as the 16th century, and due to some political designs the Kurds were organized into Emirates, (principalities) enjoying a degree of autonomy, although still under the Istanbul control (Yegen, 1996). The Kurds, as a people had been living on the frontiers of empires, borderlands, and across borders as they evolved, fashioned out complex strategies for solving issues of sovereignty and access to resources (Webinger, 2015).

It needs to be reiterated that towards the tail end of the Ottoman Empire the Kurds as a people began to enjoy some degree of developments in social life alongside the emergence of Kurdish national awareness as an intellectual movement. The French Revolution, with its ideological contents of freedom, enlightenment, nationalism and the right of man radiated to all parts of Europe. It was during this period that Kurds came in contact with the idea of nationalism which strengthened loyalty and bond among all the Kurds. In a way, therefore, the French revolution spurred the growth and development of nationalism in the social and political dictionary of the Kurds (Aydın, 2005). The nationalist sentiment thus grew among the Kurds like other nationalities within the Ottoman Empire. This nationalist urge led to the formation of secret societies so as to disentangle from the clutches of Ottoman imperial domination (Farouk-Sluglett, 1991). The response of the Ottoman leaders to Kurds aspirations was met with stiff resistance which led to periodical uprisings between 1808 and 1839 . Nearly all the resistance failed because of the inability to carry along the majority of Kurds as well as those in the administrative cadres. It also needs to be noted that the disunity among the Kurds which is a reminiscence of power struggles among various tribes led to the failure of the struggle against the centre, the Ottoman Empire (Haddad, 2001). Most Kurdish leader of the Ottoman period did not really understand what constituted the national entity of Kurds and most of the leaders also pursued personal interests instead of collective interest (Webinger, 2015). 
However, the Young Turks' revolt in 1908 had first promised to retain equal rights for all the ethnic nationalities residing within the Empire, but terminated by stopping all non-Turkish forms of cultural and political emancipation (Haddad, 2001). The nascent period of Kurdish nationalist sentiment met with conflict from Turkish authority and such led to conflict situation as opposed to peaceful co-existence between the two. From the year of Republic formation the Turkish authority has been resenting an attempt by Kurds to have regional government cum autonomy. Any attempt at having such is met with condemnation from central authority. Thus, governments of Turkey, Iran, Iraq and Syria have been practicing exclusionary policy to the detriment of the Kurds nationals within their statehood (Mango, 1999).

To be specific therefore, the study aims to examine the U.S. foreign policy towards the Kurds in the Middle East and tries to highlight the stresses and strains thereof. In addition, the research focuses on the U.S. policy towards the Kurds in Turkey and Syria and seeks to understand the reaction of these national governments to the conduct of such para-diplomacy. Such para-diplomatic activities between sub-national entities and U.S. have received criticisms from the region, most especially Turkey and Iraq. Thus, in order to better understand this, the article attempts to answer the following questions: What is the guidepost of the U.S. policy towards the Kurds in the Middle East? What are the U.S. interests with the countries that have significant Kurds' population? And lastly, is the region still important to the U.S. given the discovery of the shale oil? To provide empirical detail to these questions therefore this article examines the U.S. policy towards Syria and Turkey in relations to Kurds agitation and interest. It needs to be stressed here that it is not in the interest of this article to go into empirical detail of U.S. policy towards all these countries rather the intent of the research is to appraise in its totality the response of the superpower to Kurds' agitations in the countries mentioned. To that effect therefore, the article is segmented into sections with each looking broadly at specific issue.

\section{U.S. Foreign Policy towards the Turkish Kurds}

The U.S. and Turkey have continuously stood shoulder-to-shoulder in facing serious foreign and defense policy challenges. This close rapport started during the Korean War, in which 15,000 Turkish troops fought alongside the U.S. soldiers and to Washington's leadership in securing Turkish joining the North Atlantic Treaty Organization (NATO) in 1951 (Larrabee, 2008). During the ensuing decades, Turkey maintained the second largest military in NATO and played an important role in the defense of Europe as well as in planning for what later came to be known as "out-of-area" contingencies (Cook, 2006). The political and diplomatic relationships between the Republic of Turkey and the U.S. have always been progressive and reflective of the historical moment in time. During the Cold War, the common strategic threat posed by the Soviet Union aided the cooperation between the two countries. Yet, relations were still dictated by regional issues and domestic politics in both capitals. The traditional foundation of the U.S.-Turkey alliance has always been between the two countries' militaries, which are highly connected and integrated in the context of a harmonized NATO framework and as a result of continuous bilateral cooperation (Walker, 2010).

The end of the Cold War had an important turning point on Turkish foreign policy. During the Cold War, Turkey devoted its attention primarily on containing Soviet power and strengthening its ties with its allies in the West. The end of the Cold War, however, removed the Soviet threat, which resulted in fears among Turks that Turkey would lose its strategic importance to the U.S. These fears have proven otherwise as Turkey's strategic importance has been intensified and acknowledged. This is because the U.S. needs Turkish strategic cooperation in Eastern Europe and the Middle East (Larrabee, 2008). The pivotal goals of the U.S. in the foreign policy are to improve stability, speeding up democratization process, introduction of a free market economy, improvement in trading and commercial relations, controlling nuclear weapons and to encourage human rights standards. Thus, the main goal can be defined as blocking the spread of influence of existing radical regimes and preventing the creation of new ones (Aras, 1997). It has been said that the only places where all these goals and objectives can be attained are Middle East, Balkans and Caucasus. Therefore, Turkey remains a prime actor in many crucial issues of the U.S. in the foreign, national security, and economic policy. For six decades, a sound relationship with Turkey has been central to advancing U.S. interests in Eurasia and the Middle East and to creating new strategic opportunities for the U.S. and its other NATO allies (Flanagan \& Brannen, 2008).

In the case of the U.S. foreign policy toward the Kurds in Turkey, Kurds in Turkey are not strategically important to the U.S. unlike the Iraqi Kurds. In this manner the U.S. classified Kurdistan Workers' Party (PKK) a terrorist organization and as such assisting Turkey in mitigating the activities of this party on Turkish government. Kurds form an important minority group in Turkey as they constitute about 13 percent of the Turkey population (CIA Factbook, 2018). The Kurds form an important element in the national and social political landscape of Turkey. Despite being an important partner in the Turkish national entity, they are still not fully recognized as equal partner and such in most cases pitied the various Kurds' emancipation groups against the national government. The Central Intelligence Agency (CIA) played a major role in 1999 to capture the head of the Kurdistan Workers' Party, Abdullah Ocalan, in Nairobi. However, disagreement does exist between Turkey and the U.S. on the Democratic Union Party (PYD), which largely represents the Syrian Kurds. With the 
emergence of Islamic States in Iraq and Syria (ISIS), the U.S. used PYD to fight ISIS but Turkey believes the PYD is an extension of the PKK and in such conclusion Turkish government did not want the U.S. to support this faction as it has been declared a terrorist group. In this way, Erdogan was of the view that the U.S. has to choose between Turkey and PYD. The U.S. in this case opined that the organization should not be seen as a terrorist organization rather a group that is peaceful and civil. It is on record that Turkey descended heavily on PKK in 1980 with the U.S. weapons when the uprising arose. The Turkish government even crossed the border to Northern Iraq to deal militarily with the PKK forces. In all these the U.S. did not react in any way against such attack. It needs to be stressed here that it was in 1997 that the U.S. government designated PKK as a foreign terrorist group. In this while the Clinton government assisted the Turkey in capturing the PKK leader Abdullah Öcalan in 1999. Such capturing was made possible with the U.S. intelligence and diplomatic support to the Turkish government. The Iraqi Kurds began to enjoin the U.S. assistance only after there was intense diplomatic row between the Turkish government and the U.S. over the invasion of Iraq. In 2003, the U.S. government decided to seek for Turkish cooperation in the process of invading Iraq. Such was rejected by Ankara and such rejection led to the diversion of diplomatic relation with Iraqi Kurds. Turkey was concerned that the new Kurdistan Regional Government (KRG, now headed by Mustafa Barzani's son Masoud) could threaten Iraqi unity, and serve both as a rallying point for Kurdish irredentism inside Turkey and a safe haven for PKK militants. In an attempt at invading Kurds in Iraq by Turkey, the U.S. government prevented such attack and as well arrested eleven Turkish soldiers who were planning attack and sabotage against the Kurds in Iraq. Despite these tensions, the U.S. government assisted Turkey to deal with PKK base in Northern Iraq. This step received approval from KRG and the U.S. stepped in to assist Turkey in striking the PKK base in Northern Iraq. In 2011, announcement was made by the U.S. government to assist Turkey with advanced military equipment to employ against the PKK camps in Northern Iraq. Such assistance led to the U.S. supplying Turkey with cobra helicopters and predator drones. However, Turkish officials continued to voice frustration with the level of U.S. assistance they were receiving against PKK militants sheltering in northern Iraq, especially as clashes between Turkish security forces and PKK fighters inside Turkey intensified throughout 2012. Ankara in particular sought U.S. assistance to arrest PKK members entering KRG-controlled northern Iraq from abroad, but the U.S. reneged, fearing that this would increase tension both with the PKK and the KRG leadership in Irbil.

It needs to be said that Washington has constantly held conviction that Ankara should do more to address the grievances of its own Kurdish population. The U.S. government thus supported moves by Turkey's ruling Justice and Development Party (AKP) government to loosen restrictions on expressions of Kurdish identity within Turkey and to evolve a peace process with the PKK. U.S. officials have reiterated their support of the "Kurdish opening" that Turkish Prime Minister Recep Tayyip Erdoğan publicly made known in the summer of 2009. Nevertheless, the U.S. government still considers the PKK a potent foreign terrorist association.

The narratives above suggest that there is no significant relationship between the U.S. government and Kurdish in Turkey. The main factor that normally brings the Kurds in Turkey to the limelight is when there is political tension between the U.S. and Turkey.

\section{The U.S. Foreign policy toward the Syria Kurds}

The north, most importantly, the north east of Syria is the Kurdish strongholds and the place is known as Kurdish Syria or Rojava (Gentz., 2013). Kurds are the largest non - Arab ethnic minority in Syria. According to Human Rights Watch, there are unstable statistics on the total number of Kurds in Syria, reliable sources place the number of Kurds between 8.5 percent and 10 percent of the population of 13.8 million (CIA Factbook, 2018). Most Kurds are followers of the Sunni Muslim faith, although a large minority belong to Shi'a Muslim sects, and smaller numbers are non-Muslim, Yazidis (Neriah, 2012). The largest number of Kurds in Syria is located in Hasakeh governorate in the northeastern part of the country. Aleppo governorate in the northwest is also home to a large number of Kurds, mainly in and around Ayn al-'Arab, and in Afrin and its surrounding villages (Rusane, 2016). The Kurds of Syria, in contrast to the Kurds of Iraq and Turkey, are little known in the West, but they have similarly strained relations with the state that governs them and face human rights abuses as minority (Ziadeh, 2009). But the Syrian Kurds appeared to register their presence after the Arab Spring in 2011 and became more known after the occupation of Syria in 2014 by ISIS. It needs to be noted that the emergence of the Democratic Union Party (PYD), which allied with the PKK in combating ISIS on ground as the U.S. supporter, created more awareness about Kurds existence in Syria.

The U.S. does not have a long history of any substantial relations with Kurds in Syria until recent political debacle in the Middle East. Unlike Kurds in Iraq, Syrian Kurds have not been maintaining any long-lasting relationship with the U.S. government at official level. The relationship between Syrian Kurds and the U.S. started after the Arab Spring when the Syrian civil war broke out against Bashar Assad's regime and the relation became stronger after the emergence of ISIS (Vidal and Bitar, 2017). Washington has taken PYD as an ally to fight ISIS on the ground through the military wing of the party, the People's Protection Units (YPG) which controls the largest area in Kurdistan part of Syria. The PYD is the most powerful group in Syrian Kurdistan 
region. The PYD took control of Rojava in coordination with the forces of Bashar al-Assad, the forces withdrew from the Kurdish areas and handed them over to the Kurds without a fight. This development made both Turkey and the Syrian opposition to get angry as PYD is accused of being loyal to the regime of Bashar alAssad.

It is therefore right to assert that the Syrian civil war provided ample chance for Syrian Kurds to register their political influence and weight in Syria. In the late 2012, when the Assad regime's forces withdrew from the north of Syria, the PYD occupied three main provinces, namely Jazira, Kobani, and Afrin, and began to develop a local autonomous rule in these areas. Turkish policy makers perceived the PYD's advance in northern Syria as a threat to Turkey's national security mainly because, along with the KRG, which emerged gradually in northern Iraq beginning in the early 1990s, this would be the second Kurdish autonomous establishment in Turkey's immediate neighbourhood (Pusane, 2016).

The Kurdish question in Syria has long been a point of debate between the U.S. and Turkey. Throughout the administration of the former U.S. president, Barack Obama, the main issue shaping the U.S. strategy against ISIS was a reliance on Kurdish forces. This furtive reliance existed despite Turkish refusal to allow the Kurdishdominated Syrian Democratic Forces (SDF) to spearhead the battle to liberate Raqqa (Nidal \& Bitar, 2017). This relation got worse when the U.S. decided to arm YPG as Turkish regarded the move as a direct threat to its national security.

Turkish President accused the U.S. of creating a "pool of blood" in the region by failing to recognise Kurdish organisations as terror groups. The Turkish president was of the view that the inability of the U.S. to register Kurdish organisation as a terror group in Syria helped aggravated the political and military debacle in the Middle East. This lamentation came to the fore when the Turkish was trying to provide reason why the political stalemate in Syria would not cease as hoped. In an impassioned and sometimes angry address, Mr Erdogan asked whether the U.S. was an ally or was working with groups Ankara lists as terror organisations. (BBC, 2016). Erdogan retorted: "Hey America! How many times have we had to tell you? Are you together with us or are you with the PYD and YPG terror groups?" (News, 2016). The president's fierce reaction generated controversy in the U.S. and among the NATO allies in Europe. In such an intense diplomatic row, Turkey summoned the U.S. envoy to Ankara in protest after the U.S. State Department spokesman said that Washington did not recognise the PYD as a terror group and would continue to support its operations in Syria (Morning, 2016). Turkish concerns are focused on the apparent ascendancy in the region of the PYD, a Syrian Kurdish movement regarded as an offshoot of Turkey's banned Kurdish Workers Party (PKK). Turkey has fought an intermittent war on its own territory against the P.K.K. separatists since the 1980s. The Turkish government considers Kurdish separatists to be the greatest national security threat (Morris, 2012).

In fact, the U.S. relationship with the PYD and its military wing, YPG, is one of the biggest challenges facing the relationship between the U.S. and its strategic ally in the region, Turkey. Turkish discomfort with the U.S. support of the YPG is not based on opposition against Syrian Kurds. Despite their efforts to promote themselves as the representatives of Syrian Kurds, the YPG poses a direct national security threat to Turkey. The group is the Syrian arm of PKK, designated by Turkey, the U.S., and the European Union as a terrorist organisation, which has been fighting the Turkish government since 1984. The two groups' close ties have previously been established by the U.S. officials including the former U.S. Defense Secretary, Ash Carter, in a Senate Armed Services Committee Hearing (Ustun, 2017). The Syrian political debacle greatly altered the U.S. policy on Syrian Kurds aspirations. Washington was at first not eager to engage the Kurds in Syria, mainly as a result of concerns about the main Kurdish force, the PKK-affiliated Democratic Union Party (PYD). The U.S. experience toward the KRG in Iraq served as a lesson for engaging PYD in Syria as KRG increasingly becoming a threat to the Iraq unity. In this while the U.S. government sounded a note of warning to PYD against declaring any form of autonomy in northern Syria. In July 2013, the PYD engaged in a bloody crackdown on Kurdish antiAssad protesters in the city of Amuda in which the U.S. clearly condemned. Such criticism did not deter the U.S. government from recognizing the PYD as an important force against the Islamist groups, including those that have received Turkish support (Mnamneh, 2017). In order to improve the chances of successful combat against the Assad regime, The U.S. tried, with little success, to promote the multiparty Kurdish National Council (KNC) to serve as a reliable partner as opposed to the PYD in Syria. In doing this the U.S. persuaded the KNC to support the united opposition against Assad. It needs to be stated that the military success over al-Qaeda-linked Al-Nusra Front by PYD convinced the U.S. of the strategic importance of PYD in Syria. Shortly after the battle, Davutoğlu made a point stating that Turkey is not against the rights of any ethnic group in Syria, including the Kurds (Stansfield, 2017). In November 2013, the PYD declared it would move ahead with plans to proclaim Syrian Kurdistan independent, a move condemned by both Ankara and Barzani's KRG. In an attempt to reduce the disagreements within the Syrian Kurdish groups in the run-up to the January 2014 Geneva II Conference, talks were initiated in Irbil between representatives of the PYD and $\mathrm{KNC}$, who agreed to attend the Geneva II Conference under a united banner. Both Ankara and Washington have sought to keep the Kurdish issue off the agenda at Geneva, however, and the Syrian Kurds were not invited to Geneva as a separate group (Stansfield, 
2014). The KNC was represented only as part of Syrian opposition delegation, while the PYD was not directly represented. Washington's reluctance to engage in the Kurdish issue in Syria was largely due to the Obama administration's focus on ending the Syrian conflict. The more the conflict drags on the more the PYD looks like an effective bulwark against the spread of radicalization, the more open to engagement the U.S. is likely to be, Turkish opposition notwithstanding. Prospects for greater US-Turkish coordination on the Kurdish issue in Syria are at stake as the Syrian conflict is increasingly becoming a source of tension between Ankara and Washington. Both agree on the need to maintain Syria's territorial integrity. The U.S. has tempered its enthusiasm for rapid political change in Syria, and all but abandoned the idea of direct intervention against Assad. With few allies on the ground in Syria, Washington increasingly sees its interests aligning with those of the secular PYD. And as long as threats to the U.S. interest in Syria cannot be immediately surmounted, PYD and other Kurds groups will remain formidable partners in achieving U.S. interest.

\section{Appraisal of Kurds Overall Issue in the Middle East}

Kurds in the Middle East are been repressed by their various national governments since the collapse of the Ottoman Empire. The collapse of such mighty empire opened Kurds to the intricacies of the global politics they do not have power to control. The aftermath of the Second World War clearly open the vulnerability of the Kurds to the intricacies of international politics as the world looked intransigence to the yearnings and aspirations of the ethnic group. The eventual creation of the state of Israel in 1948 by Balfour Declaration clearly signifies that the global powers could make and unmake the world based on what they think. With the establishment of the state of Israel in 1948 and the attendant granting of independence and recognition by most western states and their allies across the globe, it implies that such political gesture could be extended to address the Kurds plight in the Middle East. Kurds are significant minority group in four countries in the Middle East and their total population is about 35 million (CIA Factbook, 2018). With such significant demography, the West should have considered extending the warm hand of statehood to Kurds in order to protect them from the political machinations of the Arabs, Turks and Persians. The reason behind such neglect could be seen from different angles. The creation of Israel itself might be a factor. How do we mean? With the creation of Israel as a state from the Palestinian entity and with the eventual subjugation of Palestine, Arabs were not contented with the whole process. Such discontentment led to Arabs' hostile relations with the West and the state of Israel. The west, most especially the U.S., might have foreseen such resentment from the Arabs and creating another state from such geographical confine would complicate the whole political and social atmosphere in the region. In this manner, facing the boomerang effect of the creation of Israel was the utmost political priority of the West and it could be politically unwise at the time to propose the creation of another state for the Kurds in the same region. One needs to recognize that the Jews after the Second World War began to direct their investment towards the U.S. and such huge investment awarded them recognition in the scheme of things in the U.S. politics. Such recognition of Jews within the U.S. might well explain the insistence of the West in the eventual partition of the Palestine to create Israel state. Another explanation advance by most scholars was the holocaust committed against the Jews in the Second World War by Nazi Germany (Mansfield, 2013; Stansfield, 2014; Natali, 2010). The aftermath of the Second World War led to group of people from the West sympathizing with the helpless nature in which the Jews were subjected. Such emotional attachment from the west might as well explain the forceful creation of Israel in the Middle East. The Kurds might as well qualify for this political gesture but the stake was too high. The aftermath of the Second World War was the time most of the countries in the Middle East began to stabilize themselves as state and most were just trying to gain independence. For example, Syria got it s independence in 1946 and Iraq subsequently attained statehood. The states of Turkey and Iran were also trying to consolidate their hold on internal socio-political terrain. In such kind of political atmosphere it could be anathema to propose the creation of Kurds state. Such proposition could be seen by the Arabs, Turkish and Persians as further attempt on the part of the West to partition and destabilize the region again. The U.S. and other western allies were just trying to establish cordial relations with the region as well as gaining the region's trust after the demise of colonialism. Thus, the proposal to establish the state of Kurds would be seen as a deliberate attempt on the part of the West to dismember some of the states where Kurds reside in the region. In essence, Kurds' plight for statehood in Iran, Syria, Iraq and Turkey are affected by twin-factor of global politics and issues within each state where Kurds reside. It needs to be state here that only Iraqi Kurds are forcefully moving in the direction of gaining self-governing status in the Middle East. The Kurds in other states are politically impotent to act the same way as Iraq Kurds. It needs to be reiterated here that Kurds, most especially the Iraqi Kurds were unlucky to have resided in a region where oil deposit is located. The main reason behind the merger of Kurdistan region of Iraq with Iraq nationhood was the discovery of large deposit of oil in Kirkuk which made the British to extend Iraq statehood to the region as a whole (Mansfield, 2013). It should also be noted that the Turkish and Iran strategic location in the region as well as an ally of the U.S. played a significant role in the direction of U.S. policy towards the Kurds. The West in general would not like to forfeit maintaining cordial relationship with some of these states. It is on record that Iran was a good ally of the U.S. during the 
heyday of Cold War against the Soviet Union. In this sense, how would one expect the issue of Kurds to become paramount to the U.S.? The same strategy repeats itself in Turkey to date in relations to Kurdistan issue. The issue of Kurds' statehood anywhere in the Middle East goes beyond the political calculation of the ethnic Kurds. What will dictate the direction of their political independence is the geo-politics of the region as a whole and this is true especially of Iraqi Kurds. The idea of securing statehood by Syrian, Iranian and Turkish Kurds is very remote unless the present political calculations in the region change. It needs to be stated here that the Washington's eagerness to align with Ankara in attempt to contain the boomerang effect of Arab Spring may lead to a political quagmire wherein the U.S. would be incapacitated to manage the Kurdish demands and emancipation process. This is because of the need to maintain the territorial integrity of both Syria and Iraq.

\section{Conclusion}

Kurds in Syria and Turkey from the foregoing have been affected by the direction of global politics and foreign policies of major powers. The U.S. foreign policy towards the Kurds in both countries essentially attuned towards achieving its personal goals and objectives in the region. As long as projecting the interest of Kurds in the region would sour the relationship with Turkey and other principal allies in the region, the U.S. cannot afford such costly venture. In addition, the U.S. is ready to compromise its stance in order to satisfy and maintain its interests in the region. When it was time to employ Peshmaga and the PYD to contain the threat of ISIS, it did. In other words, there is greater flexibility in the way and manner the U.S. conducts its foreign policy towards the Kurds in the Middle East. But as long as national interest supersedes allies' interest, the U.S. would continue to need the assistance of Kurds in maintaining and pursuing some of its interests in the Middle East.

\section{References}

Aras, B. (1997). The Place of the Palestinian-Israeli Peace Process in Turkish Foreign Policy. Journal of South Asian and Middle Eastern Studies, 20 (2).

Aydın, D. (2005). Mobilizing the Kurds in Turkey: Newroz as a Myth, (December), 132. https://doi.org/10.4324/9780203796450

BBC ( February 10, 2016). Turkey's Erdogan denounces US support for Syrian Kurds. Retrieved from https://www.bbc.com/news/world-middle-east-35541003 on 23 November, 2018.

$B B C$ (August 13, 2015) 'Barzani Asks PKK to Quit Iraqi Kurd. Retrieved from https://www.france24.com/en/20150801-kurds-iraq-barzani-pkk-enclave-turkey on December 5, 2018.

Cook, S. A. (2006). The promise of pacts. Journal of Democracy, 17(1), 63-74.

Cook, S. A. (2017). Is the World Ready for "Kurdexit"? Referendum Among Iraqi Kurds Has Middle East on Edge. Council on Foreign Relations, (September 11, 2017), 1-6. Retrieved from https://www.cfr.org/blog/world-ready-kurdexit-referendum-among-iraqi kurds-has-middle-east-edge on December 12, 2018.

Cook, S. A., \& Sherwood-Randall, E. (2006). Generating momentum for a new era in US-Turkey Relations (No. 15). Council on Foreign Relations Press.

Farouk-Sluglett, M., \& Sluglett, P. (1991). The historiography of modern Iraq. The American Historical Review, $1408-1421$

Flanagan, S. J., \& Brannen, S. (2008). Turkey's shifting dynamics: implications for U.S.-Turkey relations. Retrieved from http://books.google.com/books?id=UtAj8xuL5YcC December 10, 2018

Flanagan, S. J., \& Brannen, S. (2008). Turkey's Shifting Dynamics: Implications for US-Turkey Relations. CSIS.

Gentz., E. K. and R. P. (2013). Borders , People and the Kurdish Political Situation in Syria.

Haddad, S. (2001). THE KURDS IN TURKEY: CONTEXT AND CURRENT STATUS. Migracijske $i$ Etnicke Teme, 17(12), 87-102.

Hejab, A. (2010). Iranian Kurdistan. The Unrepresented Nations and Peoples Organization (UNPO) Is, (June 2010).

Irani, R. G. (1973). US Strategic interests in iran and saudi arabia. Journal of the US Army War College, VII (4).

Kajjo, C. S. \& S. (2011). The Evolution of Kurdish Politics in Syria | Middle East Research and Information Project Middle. Middle East Research and Information Project, 11-13.

Kaplan, M. L. (2014). Why the U.S. Backed the Kurds. The Washington Post. Retrieved from https://www.washingtonpost.com/news/monkey-cage/wp/2014/09/09/why-the-u-s backed-the-kurds/ on November 12, 2018

Katzman, K. (2017). Iran : Politics, Human Rights, and U . S . Policy.

Larrabee, F. S. (2008). Turkey as a US security partner (Vol. 694). Rand Corporation.

Mango, A. (1999). Atatürk and the Kurds. Middle Eastern Studies, 35(4), 1-25.

Mansfield, P. (2013) A History of the Middle East. London: Penguin Books Limited

Mansfield, P. (2013). A history of the Middle East. London:Penguin.

Mneimneh, H. (2017). Looking Forward to the Independence of Iraqi Kurdistan. The Washington Institute for 
Near East Policy, (August 10, 2017), 1-3.

Morris, H. (2012). Turkish Worries Over Syria Blamed on 'Kurdish Phobia .' The New York Times, pp. 1-4.

Natali, D. (2010). The Kurdish Quasi-State ...Development and Dependency in Post-Gulf War Iraq (First Edit). Syracuse University Press.

Neriah, J. (2012). The Future of Kurdistan : Between Turkey, the Iraq War, and the Syrian Revolt.

News, A. (2016). Turkish President Tayyip Erdogan accuses US of creating' pool of blood' with support of Kurds.

Nidal \& Bitar, B. (2017). The American-Turkish Relationship in Syria. The Washington Institute for Near East Policy, 1-2.

Özcan, N. A., \& Özdamar, Ö. (2009). Iran's Nuclear Program and the Future of U.S.-Iranian Relations, 121-133.

Project, T. K. (2016). A Visit to the Frontlines of the Battle Against ISIL WWI-Style Front Lines. The Kurdish Project, (May 10), 1-13.

Stansfield, G. (2014). Kurdistan Rising: To Acknowledge or Ignore the Unraveling of Iraq. Middle East Memo, 33(33), 1-16. Retrieved from http://www.brookings.edu/ /media/research/files/papers/2014/07/kurdistan iraq isis 0731/kurdistan iraq isis stansfield 0731.pdf0isis stansfield 0731

Stansfield, G. (2017). A New State in the Middle East? Republic of Kurdistan. Royal Uniited Services Institute for Defence and Security Studies, 15(September 2017), 1-12.

Ustun, K. (2017). If the US insists on supporting the YPG against Turkey's wishes, Syria' s post-ISIL stability is going to be in peril .

Walker, J. W. (2010). The United States and Turkey: Can They Agree to Disagree?. Brandeis University Crown Center for Middle East Studies, Middle East Brief, 46, 1-7.

Webinger, W. T. (2015). The Kurds, 407-409.

Yildiz, Kerim \& Taysi, B. T. (2007). The Kurds in Iran. Pluto Press.

Ziadeh, R. (2009). The Kurds in Syria. United Staes Institute of Peace 